\title{
Kaasav juhtimiskoolitus - suhtlusoskuste edendamine e-õppe ja põimõppe abil
}

\author{
Kirsti Lonka $^{\text {ab1 }}$, Elina Ketonen ${ }^{a}$, Kitte Marttinen ${ }^{c}$, Markus Talvio $^{a}$ \\ ${ }^{a}$ Faculty of Educational Sciences, University of Helsinki \\ ${ }^{b}$ Optentia Research Focus Area, Vaal Triangle Campus, North-West University \\ ${ }^{c}$ Haaga Helia University of Applied Sciences
}

\begin{abstract}
Annotatsioon
Töökohal õppimise soodustamiseks ja töötajate heaolu suurendamiseks katsetati ühes ettevõttes kaasava õpikeskkonna (ELE) mudelit. Uuringus osales 107 keskastmejuhti, kes jagati kolme rühma: e-õppe rühma $(n=42)$, võrdlusrühma $(n=42)$ ja ettevõtte moodustatud kaasava õpikeskkonna põimõppe rühma $(n=23)$, milles kasutati nii e-õpet kui ka kontaktõpet. Kõik rühmad osalesid eel- ja järeltestimises. Osalejate teadmisi hinnati 16 valikvastustega küsimuse põhjal ja teadmiste rakendamise oskusi juhtumitel põhineva keeruliste suhtlusolukordadega toimetuleku meetodi abil. Kirjeldusi selle kohta, kuidas käituda juhtumina esitatud olukordades, analüüsiti sisuanalüüsi põhimõtetest lähtudes. Seda, kas osavõtjate teadmised ja oskused koolituse tulemusena muutusid ja kas kuulumine ühte või teise rühma avaldas muutustele mõju, hinnati kordusmõõtmiste üldistatud lineaarsete mudelitega. Analüüsist ilmnes, et e-õppe rühma tulemused paranesid enam kui võrdlusrühma omad ning kaasava õpikeskkonna põimõppe rühma tulemused paranesid kõige rohkem. Seega on võimalik suhtlusoskusi veebi kaudu õppida.
\end{abstract}

Võtmesõnad: e-õpe, põimõpe, juhtimine, koolitus, sotsiaalse suhtluse oskused, veebipõhine õpe

\section{Sissejuhatus}

Artiklis kirjeldatakse, kuidas tänapäevaste pedagoogiliste meetodite abil soodustada keskastmejuhtide õppimist töökohal. Oleme veendunud, et haldusja juhtimiskoolituste tõhustamiseks on õppimise ja juhendamise valdkonnas tehtavatest uuringutest palju kasu. Ka Soome uues riiklikus õppekavas

Faculty of Educational Sciences, PO BOX 9, 00014 University of Helsinki, Finland; kirsti.lonka@helsinki.fi 
rõhutatakse tänapäevaste laiapõhjaliste oskuste, sealhulgas tööks vajalike ja ettevõtlusoskuste, samuti IKT-oskuste vajalikkust (Lonka, 2018). Püüdleme selle poole, et järgmine põlvkond omandaks need oskused lihtsa vaevaga. Palju raskem on aga õpetada praegust tööealist elanikkonda toime tulema keeruliste ja ebamääraste probleemidega, millega puututakse pidevalt kokku.

Töökohal õppimine on keeruline ja mitmemõõtmeline nähtus (Tynjälä 2008, 2013). See hõlmab kirjutamata seadusi ja ühiskondlikke tavasid, mida on sageli keeruline formaalselt sõnastada. Eelkõige käib see juhtimisoskuste kohta, mille üks osi on juhi võime lahendada organisatsioonis tekkinud väga keerulisi ja situatsioonispetsiifilisi sotsiaalseid probleeme (Mumford, Zaccaro, Connelly, \& Marks, 2000). Tänapäevased sotsiaalkonstruktivistlikud teooriad rõhutavad ühendava pedagoogika tähtsust toimetulekul kogukonna identiteedi ja rollidega ning töökeskkonnas kehtivate tavadega (Tynjälä, 2008; Wenger, 1999). Üha populaarsemaks muutuvad veebipõhise, süsteemse ja jagatud õppimise ideed, sest paljude keeruliste probleemide lahendamiseks on vaja koostööl põhinevaid jõupingutusi ja nutikaid tööriistu (Hakkarainen, Palonen, Paavola, \& Lehtinen 2004; Trilling \& Fadel, 2009). Tehnoloogia ja digiteerimine muudavad õppimist üksnes juhul, kui suudetakse muuta teadmiste rakendamise tavasid töökohas.

Oma mõjukas teadustöös on Knowles (1980) väitnud, et täiskasvanute varasemad kogemused on rikkalikuks õppimise allikaks. Seega tuleks täiskasvanute haridusprogrammides lähtuda õpitava „elulistest rakendusvõimalustest" ja õpitegevusi reastada vastavalt õppija valmisolekule õppida. Täiskasvanud soovivad omandatud oskusi ja teadmisi kohe elulistes olukordades rakendada. Sageli omandavad täiskasvanud teadmisi tõhusamalt kogemusõppe meetodite abil, eriti kui tegu on suhtlusoskustega (Aspegren, 1999; Kolb, 1984). Paljusid töökohal vajalikke oskusi on loengute kaudu keeruline õpetada. Et tõhustada töökohal õppimist, on soovitatav kasutada eri õppevorme ühendavat pedagoogilist raamistikku, milles rakendatakse protsessikeskseid meetodeid, näiteks probleem-, projekt- ja juhtumiõpet (Tynjälä, 2008).

\section{Kuidas õppijaid kaasata?}

Meie pedagoogiline käsitlusviis põhineb varem kasutatud protsessikeskse, õppijaid aktiveeriva ja kogemusliku õppimise mudelite sünteesil (Bereiter \& Scardamalia, 1993; Kolb, 1984; Lonka \& Ahola, 1995; Vermunt, 1995). Lisaks tugineb meie kaasava õpikeskkonna mudel tänapäevasele õppimis-, motivatsiooni- ja emotsioonipsühholoogiale (nt Muis et al., 2015; Pekrun, 2005). Hidi ja Renningeri (2006) neljaetapiline huvi tekitamise mudel on selle oluline osa: esiteks tekitatakse huvi (1), siis seda säilitatakse (2), kuni tekib sügavam isiklik huvi (3), mis paneb aluse osalejate pikaajalisele isiklikule huvile (4). Osalejad 
läbivad järk-järgult detailsemaks muutuva õppetsükli, mis on iseloomulik paljudele täiskasvanuõppe teooriatele (Kolb, 1984; Mezirow, 1991). Meie eesmärk oli luua nii veebipõhine kui ka põimõppe keskkond, milles on arvesse võetud varasemaid tõhusalt toiminud, sisukaid ja motiveerivaid õppemeetodeid, mida paljud täiskasvanute koolitajad hästi tunnevad.

Kaasava õpikeskkonna mudel (Lonka, 2012, 2018) põhineb osalejate tugevatel külgedel. Õpet alustatakse alati eeltestiga, seejärel läbitakse järgmised etapid.

1. Varasemate teadmiste aktiveerimine ja huvi tekitamine. Selles etapis on kõige olulisem luua osalejate jaoks tähendusrikas kontekst, mille raames saab töökohas tekkinud probleeme tuvastada ja nende üle arutleda. Eesmärk on uurida, millised on inimeste senised teadmised ja kuidas nad neid teadmisi praktikas kasutaksid. Põimõppes alustame kontaktõppega, et luua usalduslik kontakt, õppida üksteist tundma ja selgitada välja osalejate huvi.

2. Õppeprotsessi toetamine ja huvi säilitamine. Selles etapis rakendatakse veebipõhiseid õppemooduleid, kus õppematerjalid on lihtsasti kättesaadavad ning osalejad saavad oma teadmisi süvendada ja testida. Et näitlikustada, kuidas tulla toime eri olukordadega, võidakse esitada videoklippe. Ühtlasi julgustatakse õppes osalejaid omavahel suhtlema ja arutlema nii veebikeskkonnas kui ka vahetult, silmast silma kohtudes. Osalejatele antakse pidevalt kujundavat tagasisidet, et suunata neid õppimist jätkama. Eelkõige põimõppes kasutatakse kogemusõppe meetodeid, mille abil saab koos teistega suhtlusoskusi arendada (nt professionaalsete näitlejate kasutamine videoklippides).

3. Muutuste hindamine ja edasise õpimotivatsiooni toetamine. See etapp hõlmab hindamist ja järeltesti, mille abil selgitatakse välja, mida on õpitud ja kuidas protsess kulges, ning julgustatakse osavõtjaid õpitud teadmisi rakendama.

Koolituse käigus võib arusaamine teadmiste omandamisest ja õppimisest (ehk epistemoloogilised uskumused) muutuda: kui alguses peeti õppimiseks teadmiste meeldejätmist või passiivset vastuvõttu, siis hiljem hakati õppimiseks pidama teadmiste rakendamist, mõistmist ja loomist. Epistemoloogiliste uskumuste kõrgeima tasemega kaasneb arusaam, et õppimine tähendab uute vaatenurkade omaksvõttu ja isiksusena muutumist (Marton, Dall'Alba, \& Beaty, 1993). Viimasel ajal on hakatud õppimist käsitlema kollektiivse teadmiste loomisena, sest kiiresti muutuv digitaalne ja dünaamiline keskkond nõuab intensiivsemat meeskonnatööd (Lonka, Olkinuora, \& Mäkinen, 2004). Meie kogemus näitab, et kaasavas põimõppe keskkonnas korraldatud juhtimiskoolitusel võib toimuda epistemoloogiline muutus: uuritud juhid tahtsid üha enam mõelda omaenda käitumise peale, samuti hakkasid nad tajuma juhtimiskoolituse praktilist väärtust (Ketonen, Talvio, \& Lonka, 2014). 


\section{Juhtimisoskused, mis toetavad motivatsiooni ja heaolu}

Varasemates uurimustes on kirjeldatud, kuidas juhtimistavadel on sageli soovimatud ja lausa negatiivsed tagajärjed töötajate heaolule (Grant, Christianson, \& Price, 2007). Ümberkujundava juhtimise põhimõtetest lähtuvatelt juhtidelt oodatakse, et nad ei piirduks suhete muutmisega ja motiveeriksid inimesi saavutama rohkem, kui võimalikuks peetud (Bass \& Riggio, 2006). Pealegi on mõned ümberkujundava juhtimise ja vaimse heaolu vaheliste seoste uuringud näidanud, et ümberkujundav juhtimine avaldab töötajate vaimsele tervisele positiivset mõju (Arnold, Turner, Barling, Kelloway, \& McKee, 2007). Seega ei ole õppimine mitte üksnes kognitiivne, vaid ka motivatsioonil põhinev tegevus: see peaks olema sisemine ja sõltumatu, mitte väline ja sunnitud vajadus (nt Gegenfurtner, Veermans, Festner, \& Gruber, 2009; Ryan \& Deci, 2002). Õppimise puhul on täita oma osa ka emotsioonidel, huvil ja teadmishimul (nt Hidi \& Renninger, 2006; Muis et al., 2015; Pekrun, 2005). Meid huvitab aga küsimus, kuidas soodustada töökohal nii heaolu kui ka mõtestatud õppimist.

Paljudes juhtimismudelites rõhutatakse isikliku muutumise ja ümberkujunemise, mitte kitsalt juhtimisoskuste tähtsust. Samas eeldab teiste inimeste heaolu parandamine ja motivatsiooni suurendamine keerulisi sotsiaalseid oskusi, mida ei ole lihtne omandada (Talvio, 2014). Kesksete juhtimisoskuste õppimiseks leidub tähendusrikkaid viise, näiteks Gordoni loodud juhtide tõhususe treening, mis aitab omandada mõned üliolulised suhtlusoskused, näiteks konfliktilahendus- ja kuulamisoskusi (Gordon, 2001; Leader effectiveness training, $n$. d.). Selliste meetodite mõjust ei ole siiski kuigi palju teada.

Asjatundlikkuse uurimine on samuti sobiv viis läheneda töökohal õppimisele (Tynjälä, 2013). Asjatundlikkus on tavaliselt valdkonnapõhine ja eeldab mingi valdkonna sügavuti tundmist (Ericsson \& Lehmann, 1996; Ericsson \& Smith, 1991). Eri valdkondade ekspertidel on olemas deklaratiivsed teadmised ehk „teadmised, mis miski on“, mis põhinevad faktidel ja on lihtsalt sõnastatavad. Asjatundlikkuse suurenemisel peaksid nende teadmised muutuma protseduurilisteks, mis tähendab, et nad omandavad „teadmised, kuidas miski on“. Sellised teadmised on oma olemuselt sageli inertsed: neid on keeruline õpetada, õppida ja hinnata (Renkl, Mandl, \& Gruber, 1996).

Kvaliteetse juhtimisega on võimalik töötajate psühholoogilist heaolu positiivselt mõjutada (van Dierendonck, Haynes, Borrill, \& Stride, 2004). Ilmselt on aeg loobuda sellistest juhtimiskoolitustest, mis peavad teadmiste meeldejätmist olulisemaks nende omandamisest suhtluse kaudu (Hotho \& Dowling, 2010). Üllatavalt vähe on teada aga veebipõhiste koolituste mõjust juhtide ja keskastmejuhtide heaolule ning suhtlusoskustele. 


\section{Suhtluskoolitus tööl}

Mõne strateegia rakendamine võib takerduda juhtide uskumuste taha, mis on seotud asjatundlikkusega ja selle suurendamisele kaasa aitamisega. Paljud omadused, näiteks anne, IQ, emotsionaalne intelligentsus, iseloomujooned ja karisma, võivad tegelikult koosneda õpetatavatest ja õpitavatest oskustest (Ericsson, Prietula, \& Cokely, 2007). Valmisolek tegeleda juhtimisprobleemidega nõuab teadlikku pingutust. Dweck (2006) on kasutanud terminit fikseeritud mõtteviis, et tähistada uskumuste kogumit, mis taandab keerulised oskused kalduvusteks ja kaasasündinud võimeteks. Vastandina sellele viitab juurdekasvu mõtteviis keeruliste ülesannete edukale lahendamisele, näiteks suhtlusprobleemidega tegelemine töökohal (ibid.). Juurdekasvu mõtteviisi kontekstis ei loeta eksimusi läbikukkumise märgiks, vaid hoopis õppimise ja arengu allikaks. Rühmadünaamika on aga väga keeruline protsess ja inimestel võib olla raske tajuda oma osa. Meie varasem uuring aga näitas, et kaasavas põimõppe keskkonnas toimunud juhtimiskoolituse käigus vähenevad fikseeritud mõtteviisile omased arusaamad, mis viitab sellele, et juurdekasvu mõtteviisi on võimalik soodustada, kui õpetada osalejatele keeruliste suhtlusolukordade lahendamist (Ketonen et al., 2014).

Uuringud on tõestanud, et suhtlusoskusi on võimalik õpetada ja õppida. Paljud neist uuringutest on tehtud meditsiinivaldkonnas (nt Aspegren, 1999; Brown \& Bylund, 2008): põhioskusi saab omandada isegi lühikese koolitusperioodi jooksul ja vahel õpivad mehed suhtlusoskusi aeglasemalt kui naised. Hoolimata uurimistulemustest on suhtluskoolituste üldise raamistiku loomiseks seni vähe tehtud (Cegala \& Broz, 2002).

Õpetajate suhtluskoolituse kasulikkus on ilmnenud näiteks neli päeva väldanud Gordoni õpetajate tõhususe treeningu korral (Gordon, 2003; Teacher effectiveness training, $n$.d.). Üldiselt on õpetajate tõhususe treeningud andnud positiivseid tulemusi (Talvio, 2014; Talvio, Ketonen, \& Lonka, 2014; Talvio, Lonka, Komulainen, Kuusela, \& Lintunen, 2015). Nii on leitud, et osalejate oskused, näiteks kuulamisoskused, autonoomiat toetav käitumine ja valmisolek jääda teistele vastandudes konstruktiivseks, paranevad õpetajate tõhususe treeningu käigus, seevastu ebasoovitavad käitumisviisid vähenevad tunduvalt. Võrdlusrühma puhul ei täheldatud ei eel- ega järeltesti tulemuste põhjal osalejate teadmistes, oskustes ega heaolutasemes märkimisväärseid erinevusi. Õpetajate tõhususe treeningu järelmõju kestis üheksa kuud pärast kursuse läbimist: enamik osalejaid kirjeldas omandatud oskuste kasutamise viise ja peaaegu kõik osalenud õpetajad oleksid koolitust ka oma kolleegidele soovitanud. (Talvio et al., 2014) Nähtavasti oleks kõigi õpetajate osalemine sellel koolitusel aidanud õpitud teadmisi ja oskusi säilitada.

Paljudel juhtudel on teadmised ja oskused omavahel põimunud, sest probleemide lahendamiseks on tarvis kindlaid teadmisi ning asjatundlikkus on 
ülimalt valdkonnaspetsiifiline (Hodges, 2006). Näiteks olid meie varasemas uuringus (Talvio, Lonka, Komulainen, Kuusela, \& Lintunen, 2013) õpetajate teadmised suhtlusoskustest ja nende teadmiste rakendamise oskused omavahel korrelatsioonis. Samas ei taga isegi väga head teadmised ilmtingimata oskuslikku käitumist elulistes olukordades. Õpitud teadmised võivad osutuda kasutuks või on neid keeruline rakendada. Nimelt hõlmavad haldus- ja juhtimisoskused üldjuhul hulgaliselt hägusate, keeruliste ja kontekstipõhiste protseduuriliste ja praktiliste probleemide lahendamist ning paljudel juhtudel on need probleemid sotsiaalsed (Mumford et al., 2000; Tynjälä, 2008).

\section{Põim- ja e-õpe kõrghariduses ning juhtimiskoolituses}

Õppimis- ja juhtimisteooriate arenemisega paralleelselt on viimastel aastakümnetel toimunud ka suured tehnoloogilised muutused. Haridustehnoloogiast on saanud arvutipõhine ühesõpe: individuaalse õppimise asemel omandatakse teadmisi koostöö kaudu (nt Paavola, Lipponen, \& Hakkarainen, 2004). E-õpe ühendatakse üha sagedamini kontaktõppega ja sellised terminid nagu põimõppe keskkond või hübriidõppe keskkond on kõrghariduses laialt levinud (Bonk \& Graham, 2006). Meie kaasava õpikeskkonna kontseptsioon näeb ette holistilise pedagoogilise mudeli kasutamist hübriid-/põimõppe keskkonnas, kus ühendatakse füüsiline, visuaalne, mobiilne, sotsiaalne, pedagoogiline ja vaimne õpe (Lonka, 2012; Sandström, Eriksson, Lonka, \& Nenonen, 2016).

E-õpet iseloomustatakse tavaliselt kui IKT kasutamist õppe-eesmärgil, samas kui põimõppe keskkonda käsitletakse enamasti kui õppekeskkonda, kus kontaktõpe on ühendatud e-õppega (nt Bonk \& Graham, 2006). Soome kõrghariduses on kasutusele võetud mõned uued põimõppemeetodid (Marttinen, Patala, Ketonen, Ruusunen, \& Lonka, 2012), mille puhul kasutatakse IKTvahendeid nii õppimiseks kui ka õppimise sidumiseks tööeluga, näidates, et haridustehnoloogia kasutust tuleb suurendada ja õpetajaid tuleb koolitada seda rohkem rakendama. Olgugi et noorem põlvkond oskab tehnoloogiat paremini kasutada ja üliõpilaste suhtumine veebiõppesse on positiivne, on veebikursuse edukus tagatud vaid siis, kui selle ülesehitus, teadmiste edastamise viisid ja hindamine on õppijakesksed ning tõhusad (Mortagy \& Boghikian-Whitby, 2010).

E-õppe kasutamine hariduslikel eesmärkidel on maailmas väga laialt levinud ning õpetamine ja õppimine toimuvad üha enam e-õppe keskkonnas. Samas on kontaktõppel siiski mõningaid eeliseid. Paechteri ja Maieri (2010) uurimusest ilmneb, et kui üliõpilased peavad omandama oskusi enesereguleeritud õppimise teel, eelistavad nad küll veebiõpet, kuid soovivad siiski õpetaja vahetut juhendamist. Seevastu töötajate hoiakuid ja suhtumist on analüüsitud 2000 pangatöötajaga tehtud küsitluse põhjal, mille tulemused osutavad, et e-õpet 
peetakse paindlikumaks ja tänapäevasemaks õppevormiks, kuid kontaktõpet tajutakse motiveerivamana (Batalla-Busquets \& Pacheco-Bernal, 2013). Eeldasime, et nii kontaktõppe kui ka e-õppe tugevaid külgi on võimalik rakendada sellises uuenduslikus põimõppe keskkonnas, nagu seda on kaasav õpikeskkond. Oleme programmi „Noored ärigeneratsioonid“ raames rakendanud kaasava õpikeskkonna mudelit koostöös Soome Majandusteabeametiga seitsmel e-õppe kursusel, et edendada Soome keskkooliõpilaste ärialaseid ja tööeluks vajalikke oskusi. Koostöös õpetajatega on nimetatud kursusi võimalik kasutada kui lihtsalt e-õppe keskkondi või kui põimõppe keskkondi (Vaara, 2018).

Kuna tänapäeval on juhtide kontrolliv roll asendumas pigem toetava ja kaasava rolliga (Hlupic, 2014), siis tuleks ka juhtimiskoolitus ja muu täiendusõpe viia kooskõlla reaalsuse ja tänapäevase töökeskkonnaga. Grossman, Salas, Pavlas ja Rosen (2013) on kasutanud ettenäitamisel põhineva juhtimiskoolituse täiustamiseks juhendamisvõtteid. Wall ja Ahmed (2008) on ehitusspetsialistide koolituse kaudu omakorda näidanud, et õpetajal ja klassiruumis toimuval juhendamisel on põimõppes tähtis koht. Nad rõhutavad, et peale formaalse juhendamise tuleks planeerida ka mitteformaalseid tegevusi. Nende juhtumiuuring näitas, et põimõppeprogramme saab muuta ehitusspetsialistide jaoks huvitavaks, kui kasutada mitmesuguseid IKT-vahendeid, samuti võib nende vahendite lõimimine muuta programmi tõhusamaks. (Ibid.) Hoolimata sellest, et ka töökeskkonnas kasutatakse üha enam e-õpet, ei tohi kontaktõpet siiski alahinnata. Juhtimiskoolituse jaoks on tarvis luua uut tüüpi e-õppe ja põimõppe keskkondi ning kaasata seeläbi õppijat.

\section{Uuringu taust}

Üks Soome suur kindlustusettevõte tegi organisatsioonilisi muudatusi. Meiega alustati koostööd, et luua e-õppe ja põimõppe keskkond, kus saaks keskastmejuhtidele korraldada uuenduslikku juhtimiskoolitust. Kavatsesime koolituses kasutada kaasava õpikeskkonna mudelit (Lonka, 2012, 2018; Lonka \& Ketonen, 2012), et parandada töötajate heaolu ja suurendada nende osalemist tööprotsessis.

Meie eesmärk oli aidata suure kindlustusettevõtte keskastmejuhtidel, kes olid eksperdid kindlates tegevusvaldkondades (juristid, ettevõtlusspetsialistid või insenerid), rakendada ettevõtte uut strateegiat. Et teha seda edukalt, pidid nad strateegiat piisavalt hästi tundma. Samuti pidid nad tundma mitmesuguseid toiminguid ja meetodeid, mida soovitati kasutada eri tüüpi juhtimisküsimuste lahendamiseks, näiteks haiguslehele jäämine või töötajate heaolu tagamine. Kuna keskastmejuhid puutusid oma töös kokku ka mitmesuguste keeruliste suhtlusolukordadega, oli neil vaja arendada suhtlusoskust. Ainuüksi strateegia tundmisest ei piisanud, et muuta see heaks tavaks töökohal. Suht- 
lusoskus ei tekkinud sellest, et tunti strateegiat, vaid sellest, et deklaratiivsed teadmised muudeti eksperditeabeks. Siinses uurimuses kirjeldamegi, kuidas see pedagoogiline ülesanne lahendati ja kas leidis tõendamist, et püstitatud eesmärgid saavutati tänu sellele, et keskastmejuhid õppisid lahendama töökohal tekkinud keerulisi suhtlusprobleeme.

Koolituse ajal uurisime, kas osalejate õpioskused ning keeruliste olukordadega toimetulekuks vajalikud teadmised ja oskused võiksid koolituse käigus muutuda. Ühtlasi soovisime võrrelda kaasava õpikeskkonna e-õppe rühma ja võrdlusrühma tulemusi. Samuti tahtsime teada saada, mis lisaväärtust annab intensiivset kaasavat õpikeskkonda (põimõpet) pakkuv sekkumine. Selleks sõnastasime kaks uurimisküsimust.

1. Kas pärast koolitust on e-õppe rühmas osalenud töötajate teadmised ettevõtte töötervishoiu ja töötajate heaolu strateegia kohta ning nende valmisolek tegeleda keeruliste suhtlusprobleemidega (teadmiste rakendamine) märkimisväärselt paremad kui võrdlusrühmas osalenud töötajatel?

2. Kas juhtimiskoolitusele kontaktõppe lisamine kaasava põimõppe näol muudab õppimise veelgi tõhusamaks?

\section{Meetod}

\section{Sekkumine}

Uuringu käigus keskendusime keskastmejuhtide teadmistele ettevõtte töötervishoiustrateegia kohta ja nende valmisolekule neid teadmisi keerulistes suhtlusolukordades rakendada. Osalejatele anti vastamiseks identsed küsimustikud augustis (eeltest) ja oktoobri lõpus (järeltest), et uurida võimalikke muutusi eespool nimetatud mõõdetavates tulemustes.

Vaatlusaluses suures kindlustusettevõttes loodi kaks juhuvalikul põhinevat rühma: 1) e-õppe rühm $(n=42)$, kellel oli juurdepääs veebimaterjalidele, ja 2) võrdlusrühm $(n=42)$, kes täitis vaid küsimustiku. Lisaks moodustati 3$)$ kaasava põimõppe keskkonna rühm $(n=23)$, mille liikmed määras ettevõte (neid osalejaid ei saanud juhuvaliku alusel kaasata) ja kes läbis õppeprotsessi, mis hõlmas nii veebi- kui ka kontaktõpet. Personaliosakond valis kolmandasse rühma töötajad, kellel võiks nende hinnangul olla ettevõttes paljulubav karjäär.

Kindlustusettevõtte välja valitud juhtidele pakuti tsüklilist põimõpet kaasavas õpikeskkonnas, et toetada neid organisatsiooniliste muudatuste elluviimisel. Kümme nädalat kestnud õppetegevus algas augustis ja lõppes oktoobris. See oli ettevõttele kulukas protsess, sest keskastmejuhid osalesid õppes oma tööajast, saabudes kohale riigi eri osadest. Lisaks maksti kinni nende toitlustamine, ööbimine ja muud kulud. Ettevõtte siseveebi kasutati veebikeskkonnana ja kontaktõpe toimus töökohal. Samuti kohtuti veebipõhistes jututubades. 
Esimeses etapis (huvi äratamine) selgitati välja olemasolevad teadmised ja aktiveeriti need tähendusrikkas kontekstis, et õppimist juhtida ja suunata. Kontaktõppe avakohtumine korraldati augusti keskel. Üldiselt tundsid kõik osavõtjad ettevõtte strateegiat üsna hästi, kuid nad soovisid óppida seda ka rakendama. Teises etapis (huvi säilitamine) rakendati individuaalset veebiõpet, mille olid ette valmistanud personaliosakond ja kaasava õpikeskkonna töörühm. Veebiõpe ja jututubades toimunud kohtumised ühendati kuuetunnise kontaktõppega, mis toimus töötubade vormis (septembri keskel) ja mille viisid läbi kaasava õpikeskkonna koolitaja ja professionaalsed näitlejad, kes etendasid osalejatele keerulisi suhtlusolukordi. Kaasava õpikeskkonna protsessi kolmandas etapis (õpitulemuste hindamine, edasise õppimise motiveerimine) hinnati omandatud teadmisi ja õpitulemusi, et julgustada osalejaid rohkem uurima ja tekitada neis teema vastu sügavamat huvi. Viimane, kokkuvõttev kohtumine toimus oktoobri lõpus.

\section{Osalejad}

Osalejad olid ühe suure Soome kindlustusettevõtte 107 keskastmejuhti vanuses 27-63 aastat $(M=46,8, S D=8,4) .69,7 \%$ osalejatest olid naised ja 30,3\% mehed. Osalejate keskmine töökogemus juhina selles ettevõttes oli 7,7 aastat, kuid varieeruvus oli üsna suur $(S D=6,9)$. Üldine juhtimiskogemus (eri ettevõtetes kokku) oli keskmiselt 10,3 aastat, varieerudes märkimisväärselt $(S D=8,6)$.

Et teha kindlaks, kas enne koolitust esines rühmade vahel mingeid erinevusi, mis võiksid tulemusi mõjutada, tegime hii-ruut-testi kategoriaalse tunnuse (soo) ja ANOVA testi pidevate tunnuste (vanuse, juhtimiskogemuse, teadmiste ja nende rakendamise eest saadud punktide) kohta. Me ei tuvastanud ühtki statistiliselt olulist erinevust kolme rühma liikmete taustinfos (st vanus, sugu, juhtimiskogemus) ega teadmiste või nende rakendamise eest kogutud punktides, mida saadi enne kaasavas õpikeskkonnas toimunud koolitust.

\section{Vahendid ja protseduur}

\section{Teadmised töötervishoiu ja töötajate heaolu strateegia kohta}

Eel- ja järeltesti küsimustikes esitati kokku 16 valikvastustega küsimust, et hinnata teadmisi, mis on juhile vajalikud töötervishoiu ja töötajate heaolu tagamiseks. Kõigile küsimustele oli lisatud 3-7 valikvastust, mida osalejad pidid hindama kas õigeks või valeks. Küsimustikud sisaldasid üheksat küsimust ka üldiste juhtimisteemade, näiteks juhi rolli ja ülesannete kohta, samuti küsiti, kuidas käituda siis, kui töötajate heaolu on vähenenud ja töö kvaliteet halvenenud, mis on kiusamine, kuidas ennetada tööõnnetusi ja miks on oluline hoolitseda töötajate heaolu eest. Lisaks esitati seitse küsimust, millega kont- 
rolliti teadmisi ettevõtte personalijuhtimises kesksel kohal olevate eesmärkide ja reeglite kohta. Hindamisskaala ulatus 0st (kehvad teadmised) 70ni (suurepärased teadmised). Teadmiste testi koostas ettevõtte personaliosakond ja sellega mõõdeti uue strateegia tundmise tahke. Ei eeldatud, et küsimused moodustavad sidusa terviku.

\section{Teadmiste rakendamine keerulistes suhtlusolukordades}

Teadmiste rakendamist keerulistes suhtlusolukordades testiti keeruliste suhtlusolukordadega toimetuleku meetodi abil (Dealing with Challenging Interaction; vt Talvio, Lonka, Komulainen, Kuusela, \& Lintula, 2012; Talvio et al., 2013). Küsimustikud sisaldasid töötajatega seotud keeruliste olukordade juhtumeid, mida juhtidel tuli lahendada. Pärast iga juhtumi tutvustamist paluti osalejatel kirjeldada paari reaga, kuidas nad olukorrale reageeriksid. Näiteks: „Ühe teie töötaja töö kvaliteet ja tulemuslikkus on vähenenud. Tema hallatavad projektid on ajakavast maha jäänud, lisaks keeldub ta endale uusi tööülesandeid võtmast. Teised Teie tiimi liikmed on sunnitud tema projektidega tegelema, et tagada klientide rahulolu. Kuidas Te toimiksite?” (1. juhtum, töö tulemuslikkuse vähenemine). Teised kaks juhtumit käsitlesid töötaja liiga pikaks veninud tööpäevi, teiste töötajate seltskonna vältimist ja omavolilist töölt puudumist (2. juhtum, muutunud käitumine) ning töötajaskonnaga vastuollu minekut töötajatevahelise lugupidamatuse ja halva töõõhkkonna tõttu (3. juhtum, halb tööõhkkond).

Osalejate kirjeldusi selle kohta, mida nad nendes olukordades teeksid, analüüsiti ja kvantifitseeriti, hinnates vastuseid viiepunktisüsteemis vastavalt suhtlusoskust näitavale kvaliteedile (vt Frey, Botan, Friedman, \& Kreps, 1992; Talvio et al., 2012; Weber, 1990). Näiteks anti üks punkt vastuse eest, mis ei sisaldanud mingit dialoogi, vaid üksnes käskivat kõnet, samal ajal kui viis punkti sai vastus, mis hõlmas vastastikkususe aspekti, näiteks sisaldas kuulamise kirjeldusi ning toetas töötaja autonoomsust ja tegevust. Kõigi kolme juhtumi kohta enne ja pärast koolitust antud vastuseid hindasid ühel ajal, kuid iseseisvalt ettevõtteväline pedagoog ja ettevõtteväline suhtluskoolitaja. Lisaks analüüsisid kaasava õpikeskkonna juhtkoolitaja ja ettevõtte personalijuht 1. juhtumi kohta antud vastuseid. Hindajad ei teadnud, kas vastused olid antud enne või pärast koolitust, samuti mitte seda, kas vastaja kuulus kaasava õpikeskkonna, e-õppe või võrdlusrühma.

Sisemise kooskõla kindlaksmääramiseks arvutati iga juhtumi kohta hindajate Cronbachi alfa kordaja. 1. juhtumi puhul oli Cronbachi alfa eeltesti ajal 0,73 ja järeltesti ajal 0,64 , mis näitas kolme sõltumatu hindaja kombineeritud hinnangute piisavat usaldusväärsust. 2. ja 3. juhtumi puhul oli Cronbachi alfa eeltesti ajal vastavalt 0,69 ja 0,67 ning järeltesti ajal 0,77 ja 0,71 . Seega näitasid kvalitatiivsetele juhtumitele antud sõltumatud hinnangud keskmist või head sisemist kooskõla hindajate vahel ja piisavat usaldusväärsust iga juhtumi kvantifitseerimisel. 


\section{Analüïs}

Kõik analüüsid tehti IBM SPSS Statisticsi versiooni 24.0 abil. Analüüsi käigus arvutati välja iga rühma eel- ja järeltesti keskmised tulemused ning standardhälbed. Loodi neli kordusmõõtmiste üldistatud lineaarset mudelit (GLM), et teha kindlaks, kas osavõtjate teadmised ja nende rakendamise viis (kolme juhtumi puhul) muutuvad juhtimiskoolituse käigus (peamõju) ja kas osavõtjate kuulumisel kaasava õpikeskkonna, e-õppe või võrdlusrühma on sellistele muutustele mingisugune mõju (koosmõju). Igas mudelis lisati sõltuva tunnusena teadmised või teadmiste rakendamine (juhtum). Sõltumatute tunnustena (subjektidevahelised ja subjektisisesed sõltumatud tunnused) lisati kuulumine ühte rühmadest ja juhtimiskoolituse läbimine (eel- ja järeltest). Kõik tunnused lisati mudelitesse korraga ning koolituse peamõju, samuti rühmade ja koolituse koosmõju teadmistele ja nende rakendamisele uuriti korraga. Lisaks võrreldi mudeleid paarikaupa, rakendades Bonferroni parandust, et uurida, mis rühmade puhul esinesid eel- ja järeltesti keskmistes tulemustes olulised erinevused. Statistilistes analüüsides lisati igale analüüsile suurim võimalik osalejate arv.

\section{Tulemused}

Eelhindamisel ei tuvastatud ühegi juhtumi puhul statistiliselt olulisi erinevusi kaasava õpikeskkonna, e-õppe või võrdlusrühma kuulunud osalejate teadmiste ja nende rakendamise eest saadud punktides. Kõik rühmad said teadmiste eest palju punkte juba enne koolituse algust (ligi 60 punkti skaalal 0-70, vt üksikasjalikku kirjeldavat statistikat tabelis 1).

Tabel 1. Kirjeldav statistika

\begin{tabular}{|c|c|c|c|c|c|c|c|c|c|c|c|c|}
\hline \multirow[b]{3}{*}{ Tunnus } & \multicolumn{4}{|c|}{$\begin{array}{c}\text { Kaasava } \\
\text { õpikeskkonna rühm } \\
n=23\end{array}$} & \multicolumn{4}{|c|}{$\begin{array}{c}\text { E-õppe rühm } \\
n=42\end{array}$} & \multicolumn{4}{|c|}{$\begin{array}{c}\text { Võrdlusrühm } \\
n=42\end{array}$} \\
\hline & \multicolumn{2}{|c|}{ Eeltest } & \multicolumn{2}{|c|}{ Järeltest } & \multicolumn{2}{|c|}{ Eeltest } & \multicolumn{2}{|c|}{ Järeltest } & \multicolumn{2}{|c|}{ Eeltest } & \multicolumn{2}{|c|}{ Järeltest } \\
\hline & $M$ & $S D$ & $M$ & $S D$ & $M$ & $S D$ & $M$ & $S D$ & $M$ & $S D$ & $M$ & $S D$ \\
\hline Teadmised & 60,7 & 3,6 & 62,8 & 4,9 & 59,5 & 5,8 & 61,1 & 5,7 & 59,3 & 5,0 & 59,8 & 3,5 \\
\hline \multicolumn{13}{|l|}{$\begin{array}{l}\text { Teadmiste } \\
\text { rakendamine }\end{array}$} \\
\hline 1. juhtum & 3,26 & 0,75 & 3,91 & 0,65 & 3,18 & 0,77 & 3,69 & 0,69 & 3,29 & 0,83 & 3,20 & 0,66 \\
\hline 2. juhtum & 3,02 & 0,55 & 3,79 & 0,98 & 2,92 & 0,87 & 3,21 & 0,86 & 3,06 & 0,92 & 3,00 & 0,75 \\
\hline 3. juhtum & 2,89 & 0,83 & 3,22 & 1,03 & 3,01 & 0,90 & 3,12 & 0,92 & 3,06 & 0,91 & 3,18 & 0,92 \\
\hline
\end{tabular}




\section{Muutused teadmistes töötervishoiu ja töötajate heaolu strateegia kohta}

Et leida vastus esimesele uurimisküsimusele, kasutati kordusmõõtmiste üldistatud lineaarseid mudeleid, kus sõltuv tunnus oli teadmistele antud hinnang. Mõõtmistulemused näitasid, et koolitusel on teadmistele üldiselt positiivne mõju, sest saadud punktides ilmnesid statistiliselt olulised erinevused $\left[F(1,77)=11,07, p=0,001\right.$, osaline $\left.\eta^{2}=0,126\right]$. Paarikaupa võrdlusest ilmnes, et eel- ja järeltesti põhjal erinevad statistiliselt olulisel määral kaasava õpikeskkonna rühm $\left[F(1,77)=5,42, p=0,022\right.$, osaline $\left.\eta^{2}=0,066\right]$ ja e-õppe rühm $\left[F(1,77)=8,91, p=0,004, \eta^{2}=0,104\right]$, kuid mitte võrdlusrühm $[F(1,77)=0,08$, $\left.p=0,784, \eta^{2}=0,001\right]$. See viitab asjaolule, et koolitusel oli kaasava õpikeskkonna rühmale ja e-õppe rühmale positiivne mõju (vt joonis 1). Kuigi nende liikmete teadmised olid väga head juba enne koolituse algust, muutusid nii kaasava õpikeskkonna kui ka e-õppe rühma tulemused statistiliselt olulisel määral eel- ja järeltesti vahelisel ajal, mil paranesid teadmised ettevõtte strateegiast.

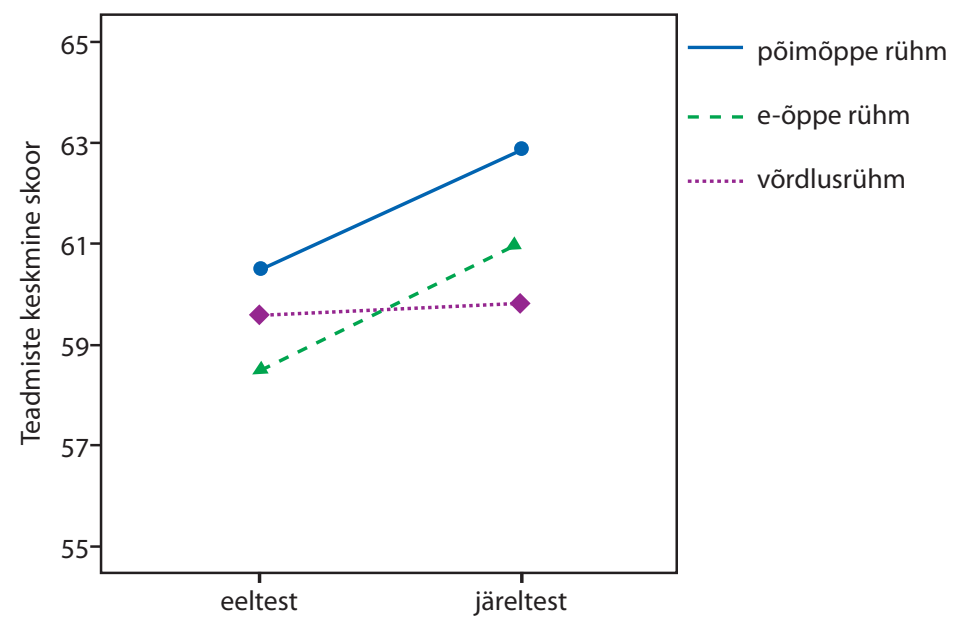

Joonis 1. Muutused rühmade teadmistes eel- ja järeltesti tulemuste põhjal

\section{Muutused, mis on seotud teadmiste rakendamisega keerulistes suhtlusolukordades}

1. juhtumi kordusmõõtmiste üldistatud lineaarse mudeli tulemused (töö tulemuslikkuse vähenemine) näitasid statistiliselt olulist positiivset muutust kõigis rühmades $\left(F(1,74)=15,89, p<0,001\right.$, osaline $\left.\eta^{2}=0,177\right)$, samuti statistiliselt olulist koolituse (ehk eel- ja järeltesti) ja rühma koosmõju $(F(2,74)=5,19$, $p=0,008$, osaline $\eta^{2}=0,123$ ). Samas, uurides koosmõju olemust ja seda, mis 
rühmades esines statistiliselt olulisi erinevusi eel- ja järeltesti tulemustes, leidsime, et muutused olid statistiliselt olulised nii kaasava õpikeskkonna rühmas $\left[F(1,74)=10,54, p=0,002\right.$, osaline $\left.\eta^{2}=0,125\right]$ kui ka e-õppe rühmas $[F(1,74)=$ $12,15, p=0,001$, osaline $\left.\eta^{2}=0,141\right]$, kuid mitte võrdlusrühmas $[F(1,74)=0,04$, $p=0,848$, osaline $\left.\eta^{2}=0,000\right]$ (vt joonis 2 ).

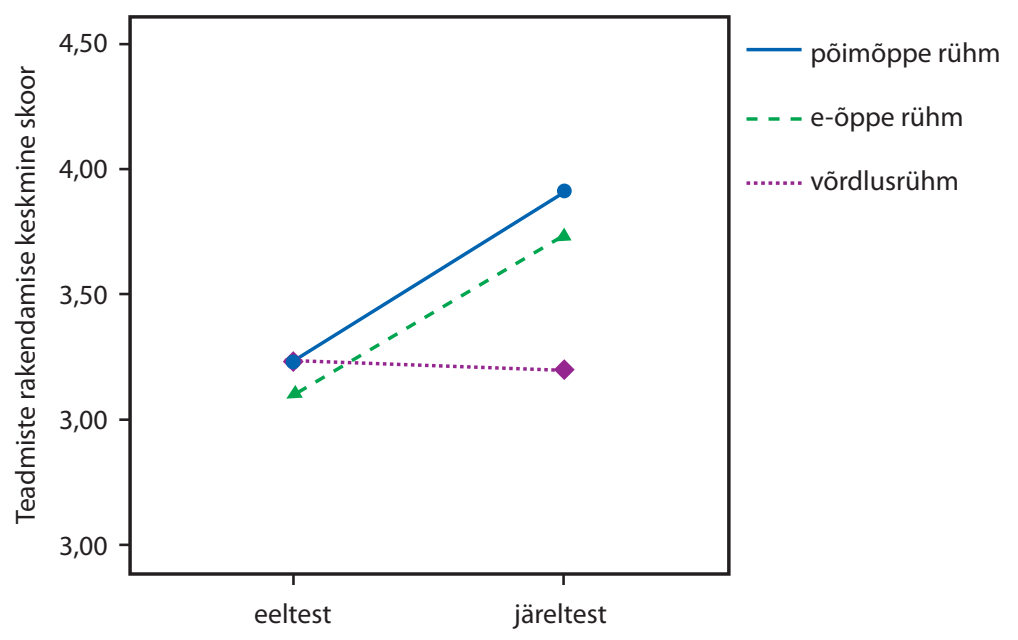

Joonis 2. Muutused rühmades 1. juhtumi (töö tulemuslikkuse vähenemine) lahendamisel eel- ja järeltesti tulemuste põhjal

Samamoodi näitasid 2. juhtumi (muutunud käitumine) lahendamise eest saadud punktid statistiliselt olulist teadmiste paranemist kaasavas õpikeskkonnas toimunud koolituse käigus $\left[F(1,72)=7,49, p=0,008\right.$, osaline $\left.\eta^{2}=0,094\right]$ ja statistiliselt olulist koolituse ja rühma koosmõju $[F(2,72)=7,12, p=0,002$, osaline $\left.\eta^{2}=0,165\right]$. Siiski tuvastati seekord statistiliselt olulisi muutusi üksnes kaasava õpikeskkonna rühma tulemustes $[F(1,72)=14,34, p<0,001$, osaline $\left.\eta^{2}=0,166\right]$. Koolituse käigus ei toimunud olulisi muutusi ei e-õppe rühma $\left[F(1,72), p=0,115\right.$, osaline $\left.\eta^{2}=0,034\right]$ ega võrdlusrühma teadmistes $[F(1,72)$ $=1,51, p=0,224$, osaline $\left.\eta^{2}=0,020\right]$ (vt joonis 3 ). 


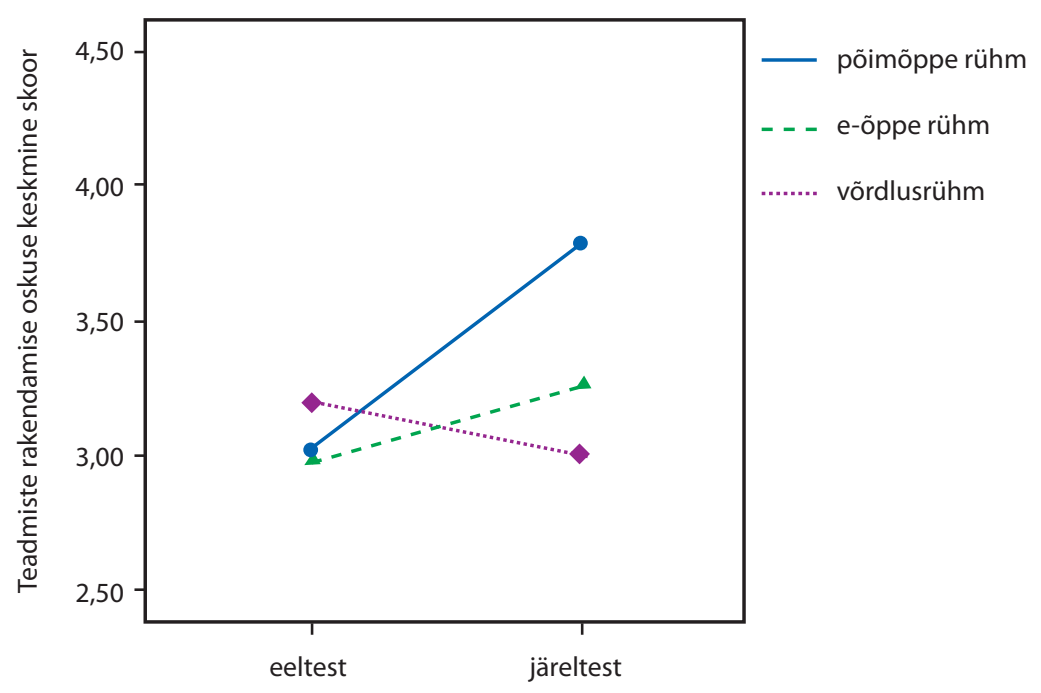

Joonis 3. Muutused rühmades 2. juhtumi (muutunud käitumine) lahendamisel eel- ja järeltesti tulemuste põhjal

Üldistatud lineaarse mudeliga saadud tulemused 3. juhtumi (halb tööõhkkond) lahendamise kohta näitasid, et koolituse mõju ei olnud statistiliselt oluline ühegi rühma puhul. Väikest positiivset nihet võis märgata kaasava õpikeskkonna rühma vastustes, kuid see ei olnud statistiliselt oluline $[F(1,71)=2,37$, $p=0,129]$ (vt joonis 4$)$.

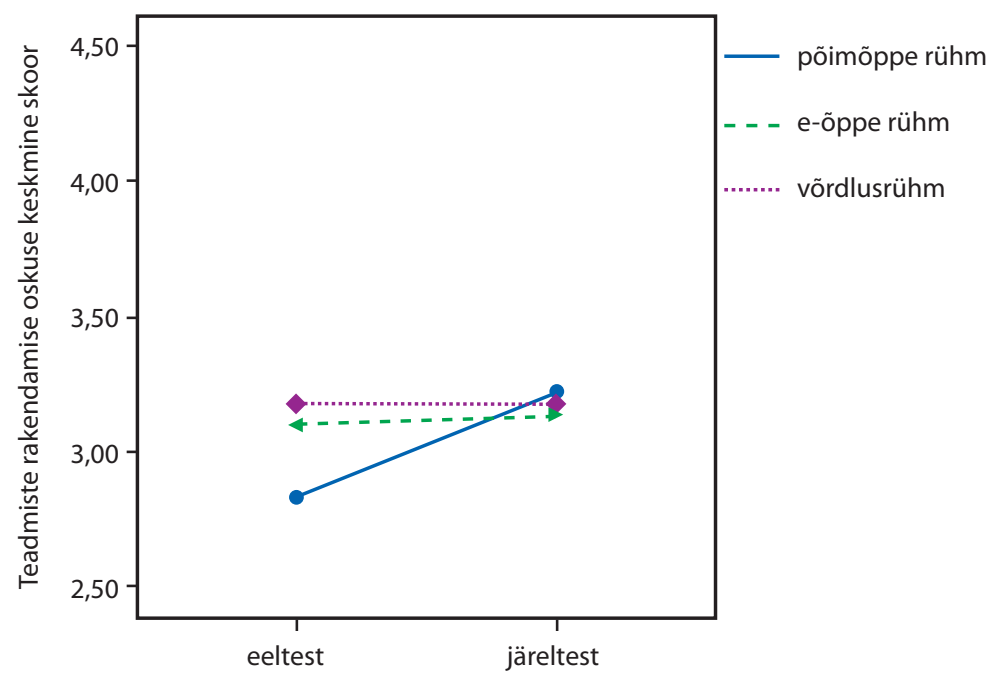

Joonis 4. Muutused rühmades 3. juhtumi (halb tööõhkkond) lahendamisel eel- ja järeltesti tulemuste põhjal 


\section{Arutelu}

Sekkumise alguses ei erinenud võrdlusrühma teadmised strateegiast ega valmisolek lahendada keerulisi suhtlusolukordi kahe teise rühma töötajate omadest. See näitab, et kuigi kaasava õpikeskkonna rühma kuulunud töötajad valis välja ettevõte selle alusel, et neist võiksid tulevikus saada edukad juhid, ei olnud nad eeltestides teiste rühmade liikmetest paremad.

Esimene uurimisküsimus puudutas e-õppe ja võrdlusrühma erinevusi. Koolituse käigus paranesid e-õppe rühma teadmised strateegiast oluliselt enam kui võrdlusrühmal. Ka 1. juhtumi lahendamisega, mis nõudis reageerimist olukorrale, kus töötaja töö kvaliteet oli halvenenud, sai e-õppe rühm pärast koolitust märkimisväärselt paremini hakkama, samal ajal kui võrdlusrühmas ei täheldatud muutusi.

Teine uurimisküsimus esitati selle kohta, kas kaasava õpikeskkonna rühm erineb teisest kahest rühmast. Selgus, et 1. juhtumi puhul paranes nii e-õppe rühma kui ka kaasava õpikeskkonna rühma teadmiste rakendamise oskus oluliselt enam kui võrdlusrühma oma. Lisaks leiti, et 2. juhtumi puhul, kus tuli tegeleda töötaja käitumisprobleemidega (pikad tööpäevad, endasse sulgumine ja omavoliline töölt puudumine), paranesid teadmiste rakendamise oskused ainult kaasava õpikeskkonna rühmal. Seevastu võrdlusrühma kuulunud töötajate tulemustes ei täheldatud koolituse käigus olulisi muutusi.

Osalejate vastustes, mis anti 3. juhtumi kohta, ei ilmnenud statistiliselt olulised muutused isegi mitte kaasava õpikeskkonna rühmal. Selle juhtumiga taheti ópetada, kuidas saada hakkama olukorras, kus valitseb lugupidamatus ja tööõhkkond on halb. Eesmärk ei olnud kontrollida suhtlusoskusi, mida oldi kaasavas õpikeskkonnas toimunud koolituse jooksul omandatud, vaid üldist võimet juhtida rühmadünaamikat ja parandada rühmavaimu. Eeltestis pakuti selle juhtumi lahendamiseks eri viise, sest osalejad juhindusid konkreetse teooria asemel oma varasematest kogemustest. Selline arusaamade mitmekesisus jäi püsima ka järeltestis, mis võib olla tingitud sellest, et kaasava õpikeskkonna koolitus ei pakkunud niivõrd keerulise probleemiga tegelemiseks piisavalt tuge ja konkreetseid tööriistu.

\section{Uuringu piirangud}

Peamine piirang seisneb selles, et kõiki rühmi ei saanud moodustada juhuslikkuse alusel. Meil puudus kontroll selle üle, keda ettevõte tahtis kaasava õpikeskkonna rühma paigutada. Uuringu korraldamine igapäevases töökeskkonnas oli ühelt poolt eelis, aga teiselt poolt valmistas see keskkond raskusi. On paratamatu, et võimalikult autentse õpikogemuse kujundamiseks tuleb teha teadusuuringutele kehtestatud reeglites mõningaid järeleandmisi. Seetõttu on 
uuringu kõige usaldusväärsemad tulemused need, mis käsitlevad erinevusi e-õppe rühma ja võrdlusrühma vahel.

Eeltoodule lisaks käsitleme piiranguna seda, et me ei tea, kas õpitulemusi hakatakse kasutama ka päris elus. Võib juhtuda, et teadmised jäävad kasutamata, kuid me püüdsime seda riski minimeerida, suunates osalejaid kasutama omandatud teadmisi võimalikult elulises keskkonnas (vt Gegenfurtner et al., 2009). Samas annab keeruliste olukordade vaatlus või nendest videoklippide tegemine huvitavat teavet teadmiste võimaliku ülekandumise kohta. Paratamatult tekib ka siin probleem, et selliseid olukordi esineb üsna harva ja seetõttu on ka andmekogumiseks õige hetke tabamine raskendatud. Samuti võib olla raske küsida töötajate arvamust või paluda neil pidada päevikut selle kohta, mis muutusi nad juhtide käitumises täheldavad, sest vaatlusaluseid olukordi esineb harva.

Meie uuringu piiranguks võib pidada ka seda, et me ei tea, kui kaua koolituse mõju tegelikult kestab. Samas me siiski usume, et koolitusel osalejad õppisid tundma konstruktiivsemaid võimalusi suhelda oma töötajatega, ja kui neil on aega mõelda, kuidas töötajate üht või teist probleemi lahendada, siis kasutavad nad koolitusel omandatud teadmisi ja oskusi. Seetõttu võiks osavõtjatelt näiteks aasta pärast küsida, mida nad koolitusest mäletavad, ja paluda neil kirjeldada mõnda keerulist olukorda, kus neil on tulnud koolitusel omandatud teadmisi ja oskusi kasutada. Selline enesekohane hinnang peegeldaks üsna hästi koolituse tajutavat pikaajalist mõju osalejatele (vt Talvio et al., 2014). Pärast kõnealust sekkumiskoolitust toimus aga ettevõtteülene suuremahuline ühinemine, mis muutis osalejate edasise jälgimise võimatuks.

\section{Kokkuvõte ja järeldused}

Üks uuringu tugevaid külgi oli asjaolu, et see oli kavandatud pooleksperimentaalsena. Lisaks ei teadnud uuringu korraldajad analüüsietapis, kas kvalitatiivsed vastused keeruliste suhtlusolukordadega toimetuleku kohta olid antud enne või pärast koolitust ja kas vastused pärinesid kaasava õpikeskkonna rühmalt, e-õppe rühmalt või võrdlusrühmalt. See tähendab, et uurijad olid tulemuste klassifitseerimisel erapooletud.

Uuring näitas, et keerulisi suhtlusoskusi on võimalik õppida ja omandada nii e-õppe kui ka põimõppe keskkonnas (1. juhtum). Samuti leiti, et mõningad suhtlusoskused omandati tõhusamalt, kui õppesse lisati kontaktõpe töötubade vormis (ka 2. juhtum). Kaasav põimõpe oli seega kokkuvõttes tõhusam kui e-õppe keskkonnas toimunud koolitus.

Kaasava õpikeskkonna kasutamine tähendas siiski palju enamat kui lihtsalt kontaktõppe lisamist e-õppele. See oli hübriidõpe, millega tugevdati õppe- 
protsessi vastavalt meie parimale arusaamale tänapäevasest pedagoogikast (Lonka, 2012; Tynjälä, 2013). Kontaktõppes olid kesksel kohal võimalikud rühmasisesed arutelud ja kaaslastelt õppimine töötubades. Osalejad väljendasid arvamust, et kontaktõppe kohtumistest oli rohkem kasu kui veebipõhistest jututubadest. Kogemusliku õppe ning koolitaja ja professionaalsete näitlejate loodud reaaleluliste olukordade kasutamine võis aidata suhtlusoskusi süvendatumalt arendada kui õppematerjali individuaalne omandamine veebis (videoklippide üksinda vaatamine).

Oluline oli, et kogu sekkumine oleks lõimitud igapäevase töökeskkonnaga ja koolitusel omandatud oskused oleksid keskastmejuhtide töös otseselt vajalikud. Rõõmustav oli näha, et koolitusel osalenud juhid väljendasid suurt valmisolekut tegelda ka kõige keerulisemate juhtumite lahendamisega. See kogemus õpetas meile, kuidas kaasata tipptasemel professionaale autentsesse süvaõppesse.

Põhitulemused võib kokku võtta järgmiselt.

- Oluline on luua e-õppe ja põimõppe keskkondi, mis põhinevad tänapäevastel haridusteooriatel ja -mudelitel.

- Ettevõtte strateegia rakendamiseks ja keskastmejuhtide suhtlusoskuste parandamiseks kasutati kaasava õpikeskkonna mudelit.

- Uuringu ülesehitus oli pooleksperimentaalne ning uuringus osales kolm rühma: e-õppe, põimõppe ja võrdlusrühm.

- Koostati autentsed juhtumipõhised hindamismeetodid, et mõõta töökohal tekkivate keeruliste olukordadega hakkamasaamist.

- Pedagoogilistele põhimõtetele rajatud keskkonnas õppisid keskastmejuhid, kuidas ettevõtte strateegiat ellu viia.

\section{Tänuavaldused}

Uuringut rahastati Soome Akadeemia projektist (308352) ja ELi Erasmus+ projektist Learning2Be (4120034). Esimese autori õppevaba semestrit rahastasid Jenni ja Antti Wihuri Sihtasutus ning Soome Akadeemia mobiilsusfond (318353).

\section{Kasutatud kirjandus}

Arnold, K. A., Turner, N., Barling, J., Kelloway, E. K., \& McKee, M. C. (2007). Transformational leadership and psychological well-being: The mediating role of meaningful work. Journal of Occupational Health Psychology, 12(3), 193-203. https://doi.org/10.1037/1076-8998.12.3.193 
Aspegren, K. (1999). BEME Guide No. 2: Teaching and learning communication skills in medicine: A review with quality grading of articles. Medical Teacher, 21(6), 563-570. https://doi.org/10.1080/01421599978979

Bass, B. M., \& Riggio, R. E. (2006). Transformational leadership (2nd ed.). Mahwah: Erlbaum.

Batalla-Busquets, J.-M., \& Pacheco-Bernal, C. (2013). On-the-job e-learning: Workers' attitudes and perceptions. International Review of Research in Open \& Distance Learning, 14(1), 40-64. https://doi.org/10.19173/irrodl.v14i1.1304

Bereiter, C., \& Scardamalia, M. (1993). Surpassing ourselves: An inquiry into the nature and implications of expertise. Chicago: Open Court.

Bonk, C. J., \& Graham, C. R. (2006). The handbook of blended learning: Global perspectives, local designs. San Francisco: John Wiley \& Sons.

Brown, R. F., \& Bylund, C. L. (2008). Communication skills training: Describing a new conceptual model. Academic Medicine, 83(1), 37-44. https://doi.org/10.1097/ACM.0b013e31815c631e

Cegala, D. J., \& Broz, S. L. (2002). Physician communication skills training: A review of theoretical backgrounds, objectives and skills. Medical Education, 36(11), 1004-1016. https://doi.org/10.1046/j.1365-2923.2002.01331.x

Dweck, C. S. (2006). Mindset: The new psychology of success. New York: Random House.

Ericsson, K. A., \& Lehmann, A. C. (1996). Expert and exceptional performance: Evidence of maximal adaptation to task constraints. Annual Review of Psychology, 47(1), 273-305. https://doi.org/10.1146/annurev.psych.47.1.273

Ericsson, K. A., \& Smith, J. (Eds.) (1991). Toward a general theory of expertise: Prospects and limits. New York: Cambridge University Press.

Ericsson, K. A., Prietula, M. J., \& Cokely, E. T. (2007). The making of an expert. Harvard Business Review, 85(7/8), 114-121.

Frey, L. R., Botan, C. H., Friedman, P. G., \& Kreps, G. L. (1992). Interpreting communication research: A case study approach. Englewood Cliffs: Prentice Hall.

Gegenfurtner, A., Veermans, K., Festner, D., \& Gruber, H. (2009). Motivation to transfer training: An integrative literature review. Human Resource Development Review, 8(3), 403-423. https://doi.org/10.1177/1534484309335970

Gordon, T. (2001). Leader Effectiveness Training (L.E.T.): The proven people skills for today's leaders tomorrow. New York: Penguin Putnam.

Gordon, T. (2003). Teacher effectiveness training. New York: Three Rivers Press.

Grant, A. M., Christianson, M. K., \& Price, R. H. (2007). Happiness, health, or relationships? Managerial practices and employee well-being tradeoffs. Academy of Management Perspectives, 21(3), 51-63. https://doi.org/10.5465/amp.2007.26421238

Grossman, R., Salas, E., Pavlas, D., \& Rosen, M. A. (2013). Using instructional features to enhance demonstration-based training in management education. Academy of Management Learning \& Education, 12(2), 219-243. https://doi.org/10.5465/amle.2011.0527

Hakkarainen, K., Palonen, T., Paavola, S., \& Lehtinen, E. (2004). Communities of networked expertise: Professional and educational perspectives. Amsterdam: Pergamon. 
Hidi, S., \& Renninger, K. A. (2006). The four-phase model of interest development. Educational Psychologist, 41(2), 111-127. https://doi.org/10.1207/s15326985ep4102_4

Hlupic, V. (2014). The management shift: How to harness the power of people and transform your organization for sustainable success. Basingstoke: Palgrave MacMillan. https://doi.org/10.1057/9781137352958

Hodges, B. (2006). Medical education and the maintenance of incompetence. Medical Teacher, 28(8), 690-696. https://doi.org/10.1080/01421590601102964

Hotho, S., \& Dowling, M. (2010). Revisiting leadership development: The participant perspective. Leadership \& Organisation Development Journal, 31(7), 609-629. https://doi.org/10.1108/01437731011079655

Ketonen, E., Talvio, M., \& Lonka, K. (2014). Engaging Learning Environment (ELE) for leadership training: Fostering interest and epistemic change. 2014 International Conference on Advanced Education and Management (ICAEM2014) (pp. 104-111). Lancaster: DEStech Publications.

Knowles, M. S. (1980). The modern practice of adult education: From pedagogy to andragogy. New York: Cambridge Books.

Kolb, D. A. (1984). Experiential learning: Experience as the source of learning and development. Englewood Cliffs: Prentice-Hall.

Leader effectiveness training L.E.T. $(n . d$.). Retrieved from http://www.gordontraining.com/leader-effectiveness-training-l-e-t/.

Lonka, K. (2012). Engaging learning environments for the future: The 2012 Elizabeth W. Stone lecture. In R. Gwyer, R. Stubbings, \& G. Walton (Eds.), The road to information literacy: Librarians as facilitators of learning (pp. 15-30). Berlin, Munich: De Gruyter Saur.

Lonka, K. (2018). Phenomenal learning from Finland. Keuruu: Edita Publishing.

Lonka, K., \& Ahola, K. (1995). Activating instruction: How to foster study and thinking skills in higher education. European Journal of Psychology of Education, 10(4), 351-368. https://doi.org/10.1007/BF03172926

Lonka, K., \& Ketonen, E. (2012). How to make a lecture course an engaging learning experience? Studies for the Learning Society, 2(2/3), 63-74.

Lonka, K., Olkinuora, E., \& Mäkinen, J. (2004). Aspects and prospects of measuring studying and learning in higher education. Educational Psychology Review, 16(4), 301-323. https://doi.org/10.1007/s10648-004-0002-1

Marton, F., Dall'Alba, G., \& Beaty, E. (1993). Conceptions of learning. International Journal of Educational Research, 19(3), 277-300.

Marttinen, K., Patala, T., Ketonen, E., Ruusunen, R., \& Lonka, K. (2012). Students' and teachers' perceptions of an innovative blended learning environment - Case Porvoo Campus. Open learning generations. Closing the gap from "generation y" to the mature lifelong learners. Paper presented in EDEN Annual Conference. Porto, Portugal.

Mezirow, J. (1991). Transformative dimensions of adult learning. San Francisco: Jossey-Bass.

Mortagy, Y., \& Boghikian-Whitby, S. (2010). A longitudinal comparative study of student perceptions in online education. Interdisciplinary Journal of E-Learning \& Learning Objects, 6(1), 23-44. https://doi.org/10.28945/1128 
Muis, K. R., Pekrun, R., Sinatra, G. M., Azevedo, R., Trevors, G., Meier, E., \& Heddy, B. C. (2015). The curious case of climate change: Testing a theoretical model of epistemic beliefs, epistemic emotions, and complex learning. Learning and Instruction, 39, 168-183. https://doi.org/10.1016/j.learninstruc.2015.06.003

Mumford, M. D., Zaccaro, S. J., Connelly, M. S., \& Marks, M. A. (2000). Leadership skills: Conclusions and future directions. Leadership Quarterly, 11(1), 155-170. https://doi.org/10.1016/S1048-9843(99)00047-8

Paavola, S., Lipponen, L., \& Hakkarainen, K. (2004). Modeling innovative knowledge communities: A knowledge-creation approach to learning. Review of Educational Research, 74(4), 557-576. https://doi.org/10.3102/00346543074004557

Paechter, M., \& Maier, B. (2010). Online or face-to-face? Students' experiences and preferences in e-learning. Internet \& Higher Education, 13(4), 292-297. https://doi.org/10.1016/j.iheduc.2010.09.004

Pekrun, R. (2005). Progress and open problems in educational emotion research. Learning and Instruction, 15(5), 497-506. https://doi.org/10.1016/j.learninstruc.2005.07.014

Renkl, A., Mandl, H., \& Gruber, H. (1996). Inert knowledge: Analyses and remedies. Educational Psychologist, 31(2), 115-121. https://doi.org/10.1207/s15326985ep3102_3

Ryan, R. M., \& Deci, E. L. (2002). Overview of self-determination theory: An organismic-dialectical perspective. In E. L. Deci \& R. M. Ryan (Eds.), Handbook of self-determination research (pp. 3-33). Rochester: University of Rochester Press.

Sandström, N., Eriksson, R., Lonka, K., \& Nenonen, S. (2016). Usability and affordances for inquiry-based learning in a blended learning environment. Facilities, 34(7/8), 433-449. https://doi.org/10.1108/F-12-2014-0097

Talvio, M. (2014). How do teachers benefit from training on interaction skills? Developing and utilising an instrument to evaluate teachers' social and emotional learning (Doctoral dissertation). Helsinki: University of Helsinki. Retrieved from http://urn.fi/URN:ISBN:978-951-51-0188-4.

Talvio, M., Ketonen, E., \& Lonka, K. (2014). How long lasting are the effects of training on interaction skills? Teachers' sample. In 2014 International Conference on Advanced Education and Management (ICAEM2014) (pp. 125-131). Lancaster: DEStech Publications.

Talvio, M., Lonka, K., Komulainen, E., Kuusela, M., \& Lintunen, T. (2012). The development of the Dealing with Challenging Interaction (DCI) method to evaluate teachers' social interaction skills. Procedia - Social and Behavioral Sciences, 69(24), 621-630. https://doi.org/10.1016/j.sbspro.2012.11.454

Talvio, M., Lonka, K., Komulainen, E., Kuusela, M., \& Lintunen, T. (2013). Revisiting Gordon's teacher effectiveness training: An intervention study on teachers' social and emotional learning. Electronic Journal of Research in Educational Psychology, 11(3), 693-716.

Talvio, M., Lonka, K., Komulainen, E., Kuusela, M., \& Lintunen, T. (2015). The development of teachers' responses to challenging situations during interaction training. Teacher Development, 19(1), 97-115. https://doi.org/10.1080/13664530.2014.979298

Teacher effectiveness training T.E.T. (n. d.). Retrieved from http://www.gordontraining.com/school-programs/teacher-effectiveness-training-t-e-t/. 
Trilling, B., \& Fadel, C. (2009). 21st century skills: Learning for life in our times. San Francisco: John Wiley \& Sons.

Tynjälä, P. (2008). Perspectives into learning at the workplace. Educational Research Review, 3(2), 130-154. https://doi.org/10.1016/j.edurev.2007.12.001

Tynjälä, P. (2013). Toward a 3-P model of workplace learning: A literature review. Vocations and Learning, 6(1), 11-36. https://doi.org/10.1007/s12186-012-9091-z

Vaara, L. J. (2018). Young business generations - a technology-mediated application of the Engaging Learning Model. K. Lonka (Ed.), Phenomenal learning from Finland (pp. 154-155). Keuruu: Edita Publishing.

Van Dierendonck, D., Haynes, C., Borrill, C., \& Stride, C. (2004). Leadership behavior and subordinate well-being. Journal of Occupational Health Psychology, 9(2), 165-175. https://doi.org/10.1037/1076-8998.9.2.165

Vermunt, J. D. (1995). Process-oriented instruction in learning and thinking strategies. European Journal of Psychology of Education, 10(4), 325. https://doi.org/10.1007/BF03172925

Wall, J., \& Ahmed, V. (2008). Lessons learned from a case study in deploying blended learning continuing professional development. Continuing professional development. Engineering, Construction and Architectural Management, 15(2), 185-202. https://doi.org/10.1108/09699980810852691

Weber, R. P. (1990). Basic content analysis (2nd. ed.). Beverly Hills: Sage. https://doi.org/10.4135/9781412983488

Wenger, E. (1999). Communities of practice: Learning, meaning, and identity. Cambridge: Cambridge University Press. 